\title{
Development of environmental tools for anopheline larval control
}

Susan S Imbahale ${ }^{1,2^{*}+}$, Collins K Mweresa ${ }^{1,2+}$, Willem Takken ${ }^{1}$ and Wolfgang R Mukabana ${ }^{2,3}$

\begin{abstract}
Background: Malaria mosquitoes spend a considerable part of their life in the aquatic stage, rendering them vulnerable to interventions directed to aquatic habitats. Recent successes of mosquito larval control have been reported using environmental and biological tools. Here, we report the effects of shading by plants and biological control agents on the development and survival of anopheline and culicine mosquito larvae in man-made natural habitats in western Kenya. Trials consisted of environmental manipulation using locally available plants, the introduction of predatory fish and/or the use of Bacillus thuringiensis var. israelensis (Bti) in various combinations.

Results: Man-made habitats provided with shade from different crop species produced significantly fewer larvae than those without shade especially for the malaria vector Anopheles gambiae. Larval control of the African malaria mosquito An. gambiae and other mosquito species was effective in habitats where both predatory fish and Bti were applied, than where the two biological control agents were administered independently.

Conclusion: We conclude that integration of environmental management techniques using shade-providing plants and predatory fish and/or Bti are effective and sustainable tools for the control of malaria and other mosquito-

borne disease vectors.
\end{abstract}

\section{Introduction}

Development activities that entail clearing of forests and/or drainage of swamps for timber, agriculture, human settlement and road construction often create suitable breeding sites for malaria mosquitoes [1-4]. Irrigated fields and areas with vegetable crops are ecologically good breeding sites for anopheline larvae [5-8] and they indirectly lead to sustained levels of malaria transmission [9]. The gradual increase in human population in western Kenya has put pressure on land available for farming and as a consequence, areas that were previously natural swamps and forests have been transformed into agricultural fields that provide suitable breeding habitats for mosquitoes.

One way of adapting to changes in land use and preventing the transmission of mosquito-borne disease may be achieved through the control of immature mosquitoes. The control of immature mosquito populations is

\footnotetext{
* Correspondence: sueimbahale@yahoo.com

† Contributed equally

'Laboratory of Entomology, Wageningen University, P.O. Box 8031, $6700 \mathrm{EH}$ Wageningen, The Netherlands

Full list of author information is available at the end of the article
}

advantageous because the larvae are usually concentrated, relatively immobile, and occupy a minimal habitat area compared with adults $[10,11]$. Several larval control programs in China, India and Sri Lanka have shown great success in controlling mosquitoes through good water management practices [12]. In Africa, malaria prevention through the control of immature mosquitoes has not received as much attention as adult mosquito control [11]. This is despite the fact that successful larval control of mosquitoes in Africa by environmental management and application of larval insecticides was reported more than half a century ago [13-15], and that there is renewed interest by the scientific community to assess the feasibility of these methods of disease control [16-20].

Mosquito larval control can be achieved through environmental (water) management, use of insect growth regulators, biological and chemical control $[10,21]$. Environmental management entails modification and manipulation of the environment, and modification or manipulation of human habitation or behaviour to prevent propagation of mosquito vectors and subsequently reduce human vector pathogen contact $[22,13]$. 
However, specifications for environmental management vary with local ecosystem structure, and hence there is no uniform environmental management recipe that is appropriate in all settings [13,23]. Biological control methods directed against mosquitoes mostly refer to the use of natural enemies such as predatory fish, invertebrate predators, and toxins produced by microbial agents [10,21,24-26].

We recently reported that, while members of communities affected by malaria are willing to take part in mosquito control activities [27], there is lack of evidencebased research on locally-applicable strategies. A longitudinal study carried out in these same communities showed that larval populations of Anopheles gambiae Giles are continuously present [5]. In the present study we investigated the potential of environmental manipulation (shade from crop and non-crop plants) and biological agents (larvivorous fish and the microbial insecticide Bacillus thuringiensis var. israelensis) for the control of anopheline mosquito larvae.

\section{Materials and methods}

\section{Study site}

The field study was conducted in Nyalenda $\left(0^{\circ} 06^{\prime} \mathrm{S}\right.$ and $34^{\circ} 46^{\prime} \mathrm{E}, 1100 \mathrm{~m}$ above sea level), a peri-urban, lowincome area in Kisumu County, western Kenya. The site represented a swamp transformed to sustain irrigated agriculture. The main economic activities were subsistence agriculture with rice, maize, sweet potatoes and vegetables under cultivation. Commercial nurseries of ornamental plants and trees were also present. The area received a total annual rainfall of $1004 \mathrm{~mm}$ and experienced a mean annual relative humidity of $64 \%$ and air temperature of $23^{\circ} \mathrm{C}$ in 2007 . The area receives short seasonal rains in the months of October through December, while long rains occur between March and June with year-to-year variation in intensity. Water present at the Nyalenda study site was in parts turbid and polluted with debris and human waste from the adjacent housing estates. Additional experiments were conducted in screen-house at the Centre of Global Health Research (CGHR), KEMRI, Kisian, located $13 \mathrm{~km}$ north-west of Kisumu city.

\section{Mosquito colony}

Anopheles gambiae Giles sensu stricto larvae (Iguhu strain) used in experiments were maintained at the KEMRI insectaries in Kisian. Each larval tray was provided with $100 \mathrm{mg}$ of brewer's yeast daily (Pharmadass Ltd., Harrow, UK).

\section{Fish colony}

A colony of Gambusia affinis (Cyprinodontiformes: Poeciliidae) was established from a wild-caught population kindly provided to us by staff of the Kenya Marine and Fisheries Research Institute (KEMFRI), Kisumu County. The mosquito-fish colony was maintained in a screenhouse at KEMRI, Kisian. The fish were fed on a locally made fish food supplement obtained from KEMFRI. Adult fish were used for screen-house trials and field experiments.

\section{Mosquito larval sampling}

Larval sampling was done using the standard dipping method with a $350 \mathrm{ml}$ mosquito dipper (Bioquip, Gardena, CA, USA) as described by Service [28]. A maximum of 10 dips were sampled from each habitat. Sampled larvae were identified based on morphological characteristics, counted and classified as anophelines and culicines. The larvae were recorded either as early instars (L1 and L2) or late instars (L3 and L4) and mosquito density was expressed as number of larvae per dip. Late instar anopheline larvae were microscopically identified to species level using existing identification keys [29]. Larval sampling was followed on weekly basis unless stated otherwise.

\section{Identification and characterization of plant cover types}

This was a preliminary study done to determine whether plant cover type had any impact on the abundance of mosquito larvae in habitats within the Nyalenda study site. Plants growing within suitable mosquito breeding habitats were identified and categorized into two broad groups: those which grew along banks of water channels and those which grew inside the water channels. Plants which grew along the banks of the water channels were grouped as food and non-food crops. Plants which grew inside water channels with roots anchored in the soil were classified as rooted emergent plants while those suspended on the water surface were grouped as floating types.

\section{Identification and mapping of traditional water management practices}

Four habitat types associated with different traditional water management practices were identified and incorporated in the design of this study. These were pools (on average $0.7 \mathrm{~m}$ deep $\times 2.1 \mathrm{~m}$ in diameter), small water canals $(15 \mathrm{~m} \times 1 \mathrm{~m} \times 0.3 \mathrm{~m}$ deep), paddies $(15 \mathrm{~m}$ $\times 15 \mathrm{~m} \times 0.5 \mathrm{~m}$ deep) and swamps used for control $(5 \mathrm{~m}$ $\times 15 \mathrm{~m} \times 0.3 \mathrm{~m}$ deep). Except for the swamps (= control), all habitats were man-made. Sampling of mosquito larvae was done on Tuesday and Friday mornings for thirteen weeks (February to May 2008) based on the procedure used under plant cover habitats. The presence or absence of plant cover of each habitat was also recorded and mosquito larvae sampled according to the procedure above. 


\section{Establishing the effect of plant cover type on mosquito breeding}

Vegetation cover types inside or along the banks of man-made water canals in Nyalenda were identified. These consisted of arrow root (Maranta arudinacea) growing along banks of water canals and inside water canals, sweet potatoes (Ipomea batatas) growing along banks of water channels, African couch grass (Cynodon dactylon) growing inside water channels, water ferns (Azolla filiculoides) growing on the water surface and open sites with no plant cover (control). Each type of habitat $(2 \mathrm{~m} \times 0.75 \mathrm{~m} \times 0.3 \mathrm{~m})$ was replicated five times. All habitats were irrigated by running water from large canals (20 m away). Silt was removed, edges of the habitats were slashed while weeds growing between the plants were uprooted on weekly basis. Each habitat type was separated from the other by $10 \mathrm{~cm}$ thick wall made up of soil/mud with a narrow inlet on the upper part to allow flow of water. Mosquito larval sampling was followed as described above.

\section{Manipulation of mosquito breeding habitats through shading}

This study was conducted for a period of 17 weeks from March to June 2007. Thirty-six mosquito breeding habitats $(1 \mathrm{~m} \times 1 \mathrm{~m} \times 0.5 \mathrm{~m})$ were created by building a shallow dyke $(0.2 \mathrm{~m})$ around each habitat. Each of the four locally grown plant species Napier grass (Pennisetum purpureum), arrow root (Maranta arudinacea), papyrus reeds (Cyperus spp.) and rice (Oryza sativa) were planted in each habitat and replicated six times. One additional habitat of rice was introduced and left intact to determine if weeding had any effect on mosquito breeding and larval survival. Another series of habitats was left unplanted (control). The habitats filled naturally with water by seepage from groundwater or from rainfall. Weeding was done once per month in all habitats, except in the unweeded rice habitats, to remove un-wanted plant species that would cause unforeseen effects on the experiment. Larval sampling was conducted using the standard dipping method as described above.

\section{Biological control of mosquito larvae Investigations of Bti and Gambusia affinis for larval control} This study was done for a period of eight weeks from November to December 2007. The main goal was to estimate the optimum number of fish and the quantity of Bti required for effective control of mosquito larvae. Six different treatments were randomly administered. These included Bti 1 day, Bti 3 days and Bti 5 days (Bti was put in water, left to stay for 1,3 and 5 days before larvae were introduced), Bti and fish, Bti only and fish only while one series was left untreated to act as a control. Each treatment was replicated 25 times. Small plastic washbasins $(27.5 \mathrm{~cm} \times 17.3 \mathrm{~cm} \times 10 \mathrm{~cm})$ filled with two litres of water collected from the Nyalenda field site to a depth of three $\mathrm{cm}$ were used. Sixty larvae consisting of 30 early (L1 and L2) and 30 late (L3 and L4) instars were randomly dispensed into each basin using a rubber pipette. Each basin containing water and larvae, were then randomly assigned the six treatments as shown above. In total, 9000 laboratory-reared larvae of An. gambiae s.s. were used. The optimum Bti dosage and concentration of $5 \mathrm{mg} / \mathrm{l}$ of water was determined based on the existing literature [30]. Preliminary trials were done with different numbers of adult fish, which were offered 60 larvae (mixed larval stages of development) and we found that four adult fish were able to consume 60 larvae in $24 \mathrm{~h}$. Different sizes of mosquito fish were used to cater for differences in predation resulting from effect of size. The number of live larvae present after introduction of the treatments in different wash basins was recorded after 24 and $48 \mathrm{~h}$ of exposure.

\section{Biological control of mosquito larvae under field conditions}

This study was done for a period of 13 weeks from February to May 2008. Thirty man- made habitats $(1 \mathrm{~m} \times 1$ $\mathrm{m} \times 1 \mathrm{~m}$ ) were created as mosquito larval habitats by building a $30 \mathrm{~cm}$ shallow dyke around each habitat. Six treatments were randomly administered as follows, Bti, $B t i+$ fish in full required amount, Bti + fish at half the required amount of each, fish introduced once, and fish introduced fortnightly, while one habitat series was left untreated to act as a control. Each treatment was replicated five times. In the man-made habitats provided with fish, an extension hole measuring $30 \mathrm{~cm} \times 30 \mathrm{~cm}$ $\times 30 \mathrm{~cm}$ was dug at the bottom to provide a hiding place for the fish whenever the water reduced to minimal levels, in order to avoid potential deaths resulting from dehydration. The average quantity of Bti applied was determined by calculating the volume of water present in the site before treatment was administered. Granule formulation of Bti was broadcasted into each sampling site at the rate of $5 \mathrm{mg} / \mathrm{l}$ of water. The total number of mixed sizes of mosquito fish $(4$ to $7 \mathrm{~cm}$ ) used was based on the feeding rate of four mosquito fish per 60 mosquito larvae per day. This was also used as the minimum number of mosquito fish applied in the respective habitats. Treatments were repeated at 14-day intervals, each time on the same day of the week, except for habitats that had predatory fish introduced onlyonce.

A similar procedure was used for biological control of mosquito larvae within man-made water canals with different vegetation cover types. Six treatments were randomly administered in canals habitat with open water 
(control), Azolla growing on the water surface, sweet potatoes and arrow roots growing along the banks of water channels, African couch grass and arrow roots growing inside the water canals. Larval sampling of mosquitoes was done $24 \mathrm{~h}$ after treatment and thereafter regular sampling of mosquito larvae was conducted twice weekly using the standard dipping method as described above.

\section{Data analysis}

Data analysis was done using SPSS 15.00 for windows (SPSS Inc, Chicago, IL, USA). The General Linear Model (GLM), multivariate analysis was used to calculate the estimated marginal means for larval densities. Generalized Linear Model (GLM), with probability for normal distribution and log linked function was used for calculation of Odds ratio and comparison of larval densities within different habitats with the control. Only anopheline larval data was included in the analysis.

\section{Results}

\section{Water management practices and larval abundance}

Anopheline larval abundance sampled from the pools, paddies and water canals was compared with the control (swamp). The abundance of early instars was significantly different in water canals $(\mathrm{P}<0.05)$ and pools $(\mathrm{P}$ $<0.05)$. Early instars were twice more likely to be sampled in pools (OR 2.328, 95\% CI 1.057-5.124) and water canals (OR 2.512, 95\% CI 1.151 - 5.482) than in the swamps. Water management practices had no significant $(\mathrm{P}>0.05)$ influence on the abundance of late instar anophelines. However, late instars were twice more likely to be found in pools (OR 2.519, 95\% CI $0.281-22.610$ ) and four times in water canals (OR 4.240, $95 \%$ CI 0.521 - 34.478) when compared with the natural swamps.

\section{Vegetation cover and larval abundance}

A total of 722 late instar larvae of anopheline mosquitoes were identified. Table 1 provides a list of plants common in the study area. A comparison of different habitats showed that open sites recorded the highest percentage of anopheline larvae $(31.16 \%$; $n=224)$ while those with arrow roots growing in water had $22.58 \%$ (n = 163), arrow roots growing along water banks $14.82 \%$ $(\mathrm{n}=107)$, African couch grass growing inside water $14.54 \%(\mathrm{n}=105)$ and sweet potatoes growing along the water banks $13.85 \%(n=100)$. The lowest percentage of anopheline larvae $(3.05 \%, n=23)$ was recorded where the water surface was covered by Azolla. The abundance of both early (OR 0.290, $\mathrm{P}=0.001$ ) and late instar larvae (OR $0.264, \mathrm{P}=0.025$ ) of anophelines was reduced by 71 and $73 \%$, respectively, in habitats covered with Azolla (Table 2). Although there were significant differences
Table 1 Plant species grown in water and along water banks in Nyalenda

\begin{tabular}{l}
$\begin{array}{l}\text { Category of } \\
\text { plants }\end{array}$ \\
$\begin{array}{ll}\text { a) Plants grown along the water banks } \\
\text { (i) Food crops } & \text { Zea mays, Phaseolus vulgaris, Phaseolus aureas, Elucine } \\
\text { coracana, Sorghum sativum, Musa paradisiaca, Brassica } & \text { spp (eg Kales), Colocasia esculenta, Manihot esculenta, } \\
& \text { Ipomea batatas, Lycopersicon sp, Saccharum officinarum, } \\
& \text { Cucurbita spp. } \\
\text { (i) Non food } & \text { Pennisetum purpureum, Digitaria scalarum, Cynodon } \\
\text { crops } & \text { communis. }\end{array}$ \\
\hline
\end{tabular}

b) Plants growing in wate

(i) Emergent Colocasia esculenta, Digitaria scalarum, Cynodon plants nlemfuensis, Cyperus rotundus, Oryza sativa,

(i) Floating Azolla filiculoides, Spirogyra spp, Rhodophyte spp, plants Phaeophyte spp

among habitats with other plant cover types (Figure 1), habitats with arrow roots recorded lower densities of both early and late instar larvae.

Anopheles gambiae s.l. and An. funestus constituted $3.05 \%(\mathrm{n}=22)$ and $1.8 \%(\mathrm{n}=13)$, respectively, of all late instar larvae of anopheline mosquitoes identified from all habitats. Anopheles gambaie s.l. $(36.36 \%, \mathrm{n}=8)$ were mostly sampled in the open habitats, while water surfaces covered with Azolla recorded the lowest number $(4.55 \%, \mathrm{n}=1)$. Compared with other habitats, An. funestus were mainly recorded in habitats with African couch grass $(53.85 \%, \mathrm{n}=7)$. Anopheles coustani Laveran, which has been reported recently as a possible vector species of malaria in East Africa [17] formed $28.81 \%$ ( $n=208$ ), while other anophelines that are nonvector species of malaria constituted $66.34 \%(n=479)$.

\section{Manipulation of mosquito breeding habitats through shading}

Young anophelines (L1 and L2) were abundant in all habitat types but the numbers of late stage larvae (L3 and L4) were fewer in most habitats except in the controls, weeded rice and habitats covered by Napier grass (Table 3). The densities of young anophelines were significantly reduced by $58 \%(\mathrm{OR}=0.414, \mathrm{P}=0.002), 51 \%$ $(\mathrm{OR}=0.488, \mathrm{P}=0.038)$ and $42 \%(\mathrm{OR}=0.577, \mathrm{P}=$ 0.051 ) in habitats with Napier grass, unweeded rice and arrow roots, respectively, when compared with control habitats. Late stage larvae were significantly reduced by $95 \%$ in habitats where arrow roots were grown $(\mathrm{OR}=$ $0.045, \mathrm{P}=0.004)$, and by $91 \%$ in habitats containing unweeded rice $(\mathrm{OR}=0.091, \mathrm{P}=0.026)$, when compared with the control habitats (Table 3 ).

Overall, anophelines comprised 29\% of the total larval population sampled $(\mathrm{N}=2445)$; while culicines $(71 \%)$ were most abundant. Almost $85 \%$ of all Anopheles gambiae s.l. collected were from the control habitats while 
Table 2 Abundance of early and late instar larvae of anopheline mosquitoes in man-made habitats covered with different plant covers

\begin{tabular}{|c|c|c|c|c|c|c|c|c|c|c|}
\hline \multicolumn{6}{|c|}{ Early instars } & \multicolumn{5}{|c|}{ Late instars } \\
\hline Parameter & EMM & $\begin{array}{l}95 \% \mathrm{Cl} \text { of } \\
\mathrm{EMM}\end{array}$ & $\begin{array}{l}\text { Odds } \\
\text { ratio }\end{array}$ & $\begin{array}{l}95 \% \mathrm{Cl} \text { for } \operatorname{Exp} \\
\text { (B) }\end{array}$ & $P$ & EMM & $\begin{array}{l}95 \% \mathrm{Cl} \text { of } \\
\mathrm{EMM}\end{array}$ & $\begin{array}{l}\text { Odds } \\
\text { ratio }\end{array}$ & $\begin{array}{l}95 \% \mathrm{Cl} \text { for } \operatorname{Exp} \\
\text { (B) }\end{array}$ & $P$ \\
\hline Azolla & 0.450 & $0.064-0.964$ & 0.290 & $0.144-0.584$ & $0.001^{*}$ & 0.236 & $0.030-0.502$ & 0.264 & $0.082-0.847$ & $0.025^{*}$ \\
\hline Arrow roots inside water & 1.343 & $0.829-1.857$ & 0.866 & $0.491-1.526$ & 0.620 & 0.757 & $0.491-1.023$ & 0.848 & $0.535-1.343$ & 0.482 \\
\hline $\begin{array}{l}\text { Arrow roots on the water } \\
\text { banks }\end{array}$ & 1.557 & $1.043-2.071$ & 1.005 & $0.619-1.631$ & 0.985 & 0.657 & $0.391-0.923$ & 0.736 & $0.446-1.216$ & 0.231 \\
\hline Couch grass & 1.486 & $0.972-2.000$ & 0.959 & $0.595-1.545$ & 0.862 & 0.829 & $0.563-1.095$ & 0.928 & $0.599-1.437$ & 0.738 \\
\hline Sweet potato outside & 1.757 & $1.243-2.271$ & 1.134 & $0.711-1.808$ & 0.599 & 0.786 & $0.520-1.052$ & 0.880 & $0.561-1.381$ & 0.576 \\
\hline Control & 1.550 & $1.036-2.064$ & 1 & & & 0.893 & $0.627-1.159$ & 1 & & \\
\hline
\end{tabular}

* shows larval densities that are significantly different from the control. EMM = estimated marginal mean $\mathrm{Cl}=$ confidence interval; $\mathrm{P}=$ significance level at $95 \%$.

An. coustani was present in all habitats except the unweeded rice habitats (Figure 2).

\section{Efficacies of Bacillus thuringiensis var israelensis and Gambusia affinis for mosquito larval control}

The percentage of larvae that was alive after 24 and 48 $\mathrm{h}$ of exposure to different treatments was quite low. Treatment with Bti recorded a few pupating larvae, but the resulting pupae were unable to develop into adults. Analysis of variance found significant differences among the treatments $(\mathrm{F}=16.457 ; \mathrm{df}=4 ; \mathrm{P}<0.001)$. Pairwise comparison of different treatments showed that the number of larvae exposed to Bti and fish, Bti 1 day, Bti 3 days and Bti 5 days were not statistically different (P = 1.0) from each other. However, apart from the control, treatment with fish recorded significantly more surviving larvae after $24 \mathrm{~h}$ when compared to those treated with Bti 1 day, Bti 3 days and Bti 5 days old ( $\mathrm{P}<$ 0.001).

\section{Efficacy of Bti and fish in man-made habitats}

Anopheline larvae were sampled more from the control and in habitats with fish only (Table 4), whereas more culicine larvae (data not shown) were recorded in habitats treated with full amounts of Bti and fish. The effect of treatment type on young instars were significantly observed in habitats provided with Bti and fish, in half $(\mathrm{OR}=0.650, \mathrm{P}=0.004)$ and full $(\mathrm{OR}=0.325, \mathrm{P}<$ $0.001)$ quantities of the required amount when compared to the control habitats. However, for the late

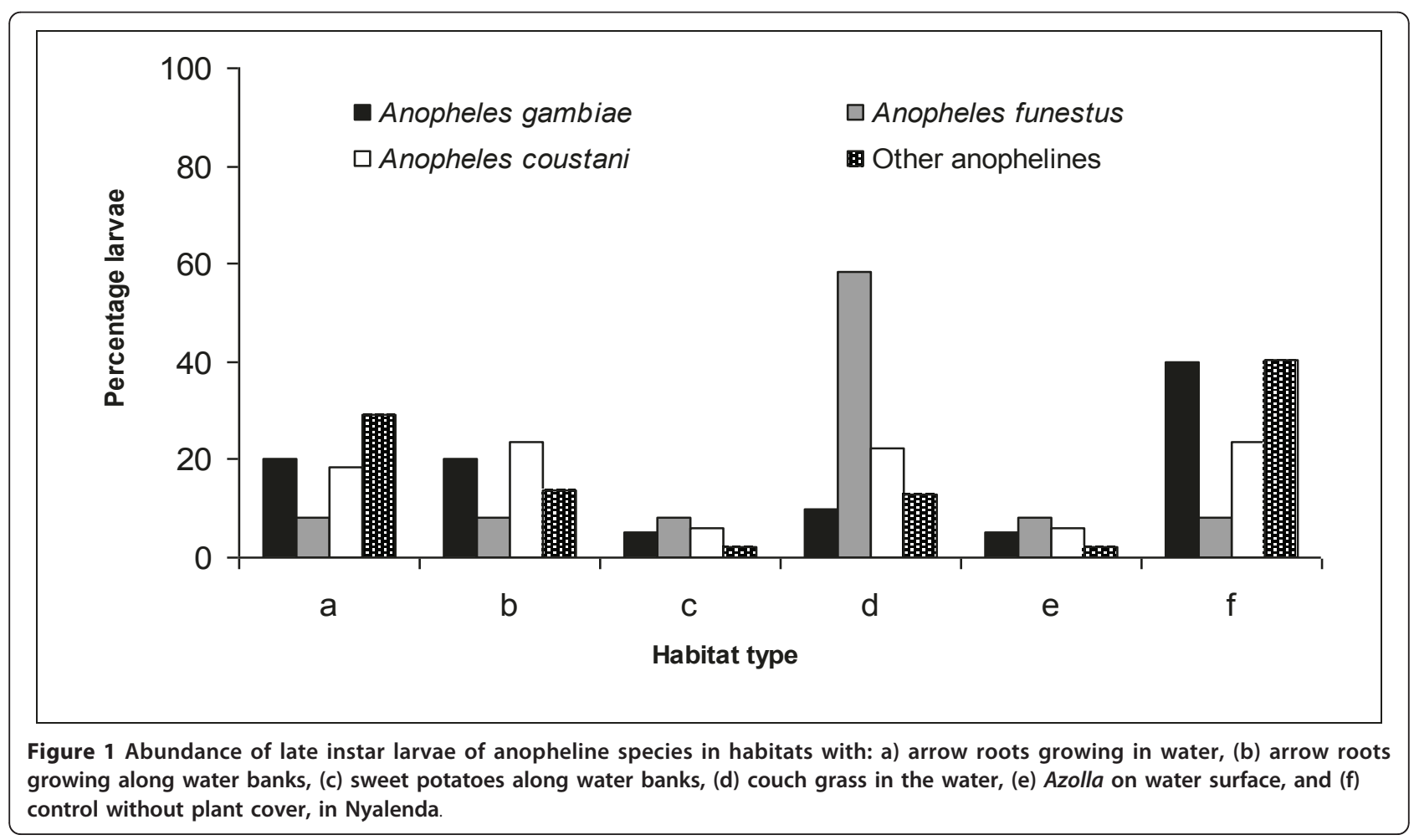


Table 3 Abundance of early and late instar larvae of anopheline mosquitoes in man-made habitats with different plant covers

\begin{tabular}{|c|c|c|c|c|c|c|c|c|c|c|}
\hline \multicolumn{6}{|c|}{ Early instars } & \multicolumn{5}{|c|}{ Late instars } \\
\hline Parameter & EMM & $\begin{array}{l}95 \% \mathrm{Cl} \text { for } \\
\mathrm{EMM}\end{array}$ & $\begin{array}{l}\text { Odds } \\
\text { ratio }\end{array}$ & $\begin{array}{l}95 \% \mathrm{Cl} \text { for } \operatorname{Exp} \\
\text { (B) }\end{array}$ & $P$ & EMM & $\begin{array}{l}95 \% \mathrm{Cl} \text { for } \\
\text { EMM }\end{array}$ & $\begin{array}{l}\text { Odds } \\
\text { ratio }\end{array}$ & $\begin{array}{l}95 \% \mathrm{Cl} \text { for } \operatorname{Exp} \\
\text { (B) }\end{array}$ & $P$ \\
\hline Arrow roots & 1.100 & $0.683-1.517$ & 0.577 & $0.332-1.003$ & $0.051^{*}$ & 0.006 & $0.036-0.048$ & 0.045 & $0.005-0.380$ & $0.004^{*}$ \\
\hline $\begin{array}{l}\text { Unweeded } \\
\text { rice }\end{array}$ & 0.929 & $0.339-1.520$ & 0.488 & $0.247-0.962$ & $0.038^{*}$ & 0.012 & $0.047-0.071$ & 0.091 & $0.011-0.755$ & $0.026^{*}$ \\
\hline Weeded rice & 1.353 & $0.763-1.943$ & 0.710 & $0.387-1.303$ & 0.269 & 0.094 & $0.035-0.153$ & 0.727 & $0.227-2.334$ & 0.593 \\
\hline Papyrus & 1.976 & $1.386-2.567$ & 1.037 & $0.621-1.731$ & 0.889 & 0.035 & $0.024-0.094$ & 0.273 & $0.052-1.442$ & 0.126 \\
\hline Napier & 0.788 & $0.371-1.206$ & 0.414 & $0.238-0.718$ & $0.002^{*}$ & 0.065 & $0.070-0.189$ & 0.500 & $0.177-1.410$ & 0.190 \\
\hline Control & 1.906 & $1.316-2.496$ & 1 & & & 0.129 & $0.023-0.107$ & 1 & & \\
\hline
\end{tabular}

* shows larval densities that are significantly different from the control. EMM = estimated marginal mean $\mathrm{Cl}=$ confidence interval; $\mathrm{P}=$ significance level at $95 \%$.

instars, habitats with $B t i$ and fish, half were marginally significant in comparison to the control whereas habitats provided with full quantities of Bti and fish were significantly different $(\mathrm{OR}=0.344, \mathrm{P}<0.001)$ (Table 4).

In man-made canals, all treatment types were significantly different from the control (all $\mathrm{P}<0.05$ ). There was an overall reduction of $73.03 \%$ in the population of all larval stages of anopheline mosquitoes. Late instar larvae of anopheline mosquitoes were reduced by $87 \%$ $(\mathrm{n}=173), 59 \%(\mathrm{n}=117)$ and $92 \%(\mathrm{n}=183)$ due to application of Bti only, fish only and Bti and fish, respectively. When compared with the control, late instars were reduced by $89 \%$ (OR $0.106, \mathrm{P}<0.001$ ) and $86 \%$ (OR 0.137, $\mathrm{P}<0.001$ ) in habitats with Bti and fish, and those with Bti only, respectively. Generally, more larvae were recorded in both ponds and canals provided with fish as the only control option (Table 4).
Anopheles gambiae s.l. was recorded in all habitats except those provided with $B t i$ and fish in full quantities, whereas more $A n$. coustani were recorded from habitats containing Bti alone (Figure 3A). The population of An. gambiae reduced by $83.33 \%$ due to Bti only, $50 \%$ by mosquito fish, while both mosquito fish and $B t i$ caused a reduction of $100 \%$. Anopheles funestus was only recorded in control habitats (Figure 3B).

\section{Discussion}

Simple strategies such as locally cultivated cover crops and plants to provide shade over mosquito breeding habitats as well as the use of predatory fish in combination with $B t i$ are feasible options for the control of immature mosquitoes, including malaria vector species. All habitats provided with shade from Azolla, sweet potatoes, arrow root, Napier grass, rice and papyrus

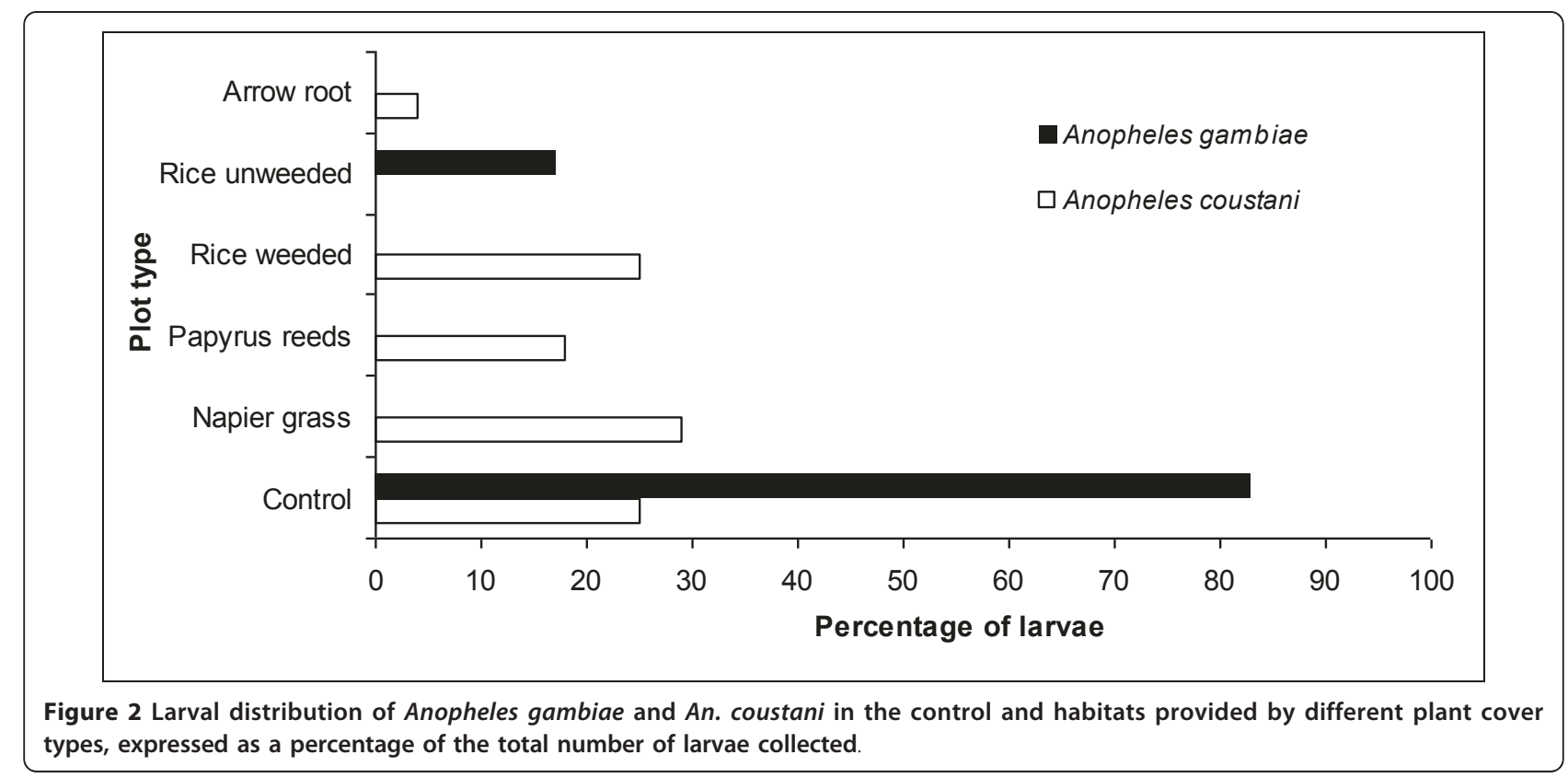


Table 4 The distribution of early and late instars of Anopheline mosquitoes in man-made habitats $(A=$ ponds, B = water canals) provided with different treatments

\begin{tabular}{|c|c|c|c|c|c|c|c|c|c|c|c|}
\hline \multicolumn{7}{|c|}{ Early instars } & \multicolumn{5}{|c|}{ Late instars } \\
\hline Variable & Parameter & EMM & $\begin{array}{l}95 \% \mathrm{Cl} \text { for } \\
\text { EMM }\end{array}$ & $\begin{array}{l}\text { Odds } \\
\text { Ratio }\end{array}$ & $\begin{array}{l}95 \% \mathrm{Cl} \text { for } \operatorname{Exp} \\
\text { (B) }\end{array}$ & $\mathbf{P}$ & EMM & $\begin{array}{l}95 \% \mathrm{Cl} \text { for } \\
\mathrm{EMM}\end{array}$ & $\begin{array}{l}\text { Odds } \\
\text { Ratio }\end{array}$ & $\begin{array}{l}95 \% \mathrm{Cl} \text { for } \operatorname{Exp} \\
\text { (B) }\end{array}$ & $P$ \\
\hline \multirow[t]{6}{*}{ A) Ponds } & Bti only & 2.376 & $1.926-2.826$ & 0.891 & $0.679-1.169$ & 0.404 & 0.570 & $0.364-0.776$ & 0.752 & $0.475-1.192$ & 0.225 \\
\hline & Fish only & 3.067 & $2.604-3.505$ & 1.145 & $0.899-1.460$ & 0.272 & 0.903 & $0.697-1.109$ & 1.192 & $0.793-1.791$ & 0.398 \\
\hline & $\begin{array}{l}\text { Bti -Fish } \\
\text { (half) }\end{array}$ & 1.733 & $1.283-2.183$ & 0.650 & $0.486-0.869$ & $0.004^{*}$ & 0.485 & $0.279-0.691$ & 0.640 & $0.405-1.012$ & $0.056^{*}$ \\
\hline & Fish Once & 2.667 & $2.217-3.117$ & 1.000 & $0.786-1.272$ & 1.000 & 0.964 & $0.757-1.170$ & 1.272 & $0.844-1.916$ & 0.250 \\
\hline & $\begin{array}{l}\text { Bti -Fish } \\
\text { (full) }\end{array}$ & 0.867 & $0.417-1.317$ & 0.325 & $0.211-0.499$ & $0.000^{*}$ & 0.261 & $0.054-0.467$ & 0.344 & $0.190-0.623$ & $0.000^{*}$ \\
\hline & Control & 2.667 & $2.217-3.117$ & 1 & & & 0.758 & $0.551-0.964$ & 1 & & \\
\hline \multirow{4}{*}{$\begin{array}{l}\text { B) Water } \\
\text { canals }\end{array}$} & Bti only & 0.635 & $0.115-1.156$ & 0.186 & $0.120-0.289$ & $0.000^{*}$ & 0.161 & $0.042-0.365$ & 0.137 & $0.068-0.278$ & $0.000^{*}$ \\
\hline & Fish only & 1.906 & $1.386-2.427$ & 0.558 & $0.374-0.832$ & $0.004^{*}$ & 0.547 & $0.344-0.750$ & 0.465 & $0.288-0.750$ & $0.002^{*}$ \\
\hline & Bti-Fish & 0.740 & $0.219-1.260$ & 0.216 & $0.143-0.327$ & $0.000^{*}$ & 0.125 & $0.078-0.328$ & 0.106 & $0.056-0.200$ & $0.000^{*}$ \\
\hline & Control & 3.417 & $2.896-3.937$ & 1 & & & 1.177 & $0.974-1.380$ & 1 & & \\
\hline
\end{tabular}

* shows habitats that are significantly different from the control. EMM = estimated marginal mean; $\mathrm{Cl}=$ confidence interval; $\mathrm{N}=$ number of times sampled; $\mathrm{P}=$ significance level at $95 \%$.

reeds supported significantly fewer anopheline larvae than the controls.

Habitats provided with shade did not have An. gambiae s.l. except for the unweeded rice, while An. coustani, a less important malaria vector, was recorded in all the habitats except in unweeded rice habitats. These effects exceeded our expectations, because An. gambiae s.l. was never recorded from treated sites except from unweeded rice, where it was found once. By contrast, An. gambiae was frequently present in unshaded control sites. Anopheles funestus, a malaria vector species of secondary local importance, was more sampled in canal habitats covered with couch grass. Longitudinal studies in Nyalenda established that An. arabiensis was the main species of the An. gambiae complex found in this area [5]. Anopheles arabiensis thrives best in open, sunlit transient habitats $[29,31]$ hence shading potential breeding habitats might have affected its abundance.

There was an overall reduction in larval populations within habitats provided with cover crops or plants. As the crops grew taller, increase in height was directly proportional to shade over the mosquito habitat before the crop reached maturity and started to senesce. The findings are in agreement with other studies that found heavy shade to be negatively correlated with larval abundance of anophelines in breeding sites [2,32-35]. Previous studies carried out in Uganda showed that $A n$. gambiae s.l. did not breed in the interior of papyrus swamps in their natural, undisturbed state [36]. In our study papyrus reed seedlings were transplanted into man-made habitats, hence they were not in their natural state and a reasonable abundance of both anopheline and culicine larvae were recorded within the habitats. The main malaria vector in western Kenya, prefers open, sunlit pools of water, however such habitats become unsuitable for ovipositing females when shade increases [6]. This is probably caused by the action of shade, which lowers the water temperature and reduces algal growth. Gravid female mosquitoes select to oviposit in sun-exposed sites [37].

The numbers of An. gambiae s.l. mosquito larvae recorded $24 \mathrm{~h}$ and $48 \mathrm{~h}$ after exposure to treatment was significantly influenced by treatment type. However, manmade habitats provided with both Bti and fish resulted in greater reductions of anopheline larval population densities when compared to habitats where only G. affinis was introduced. These results are comparable to the outcome of experiments conducted by Blaustein [38] where G. affinis alone failed to control mosquitoes in experimental rice habitats. These results indicate that the predatory effectiveness of mosquito fish on anopheline mosquito larvae diminished when introduced into the man-made larval habitats. The contrast in the findings could be attributed to other factors that we did not investigate/foresee, such as fish preying on other aquatic organisms, external food or invertebrate sources and physical factors such as turbidity. Homski et al. [39] found that higher turbidity in manmade habitats may have favored a higher abundance of invertebrates and reduced visibility of anopheline larvae for mosquito fish than in sites covered with emergent vegetation. In addition, under natural circumstances other fish species may be better predators on anopheline larvae [40]. The findings on larval control options suggest that $G$. affinis and $B t i$, when used together in the right quantities complement each other and are more effective in reducing mosquitoes in man-made habitats.

In this study, Bti was applied in habitats once in a fortnight, which matched with larviciding studies, 


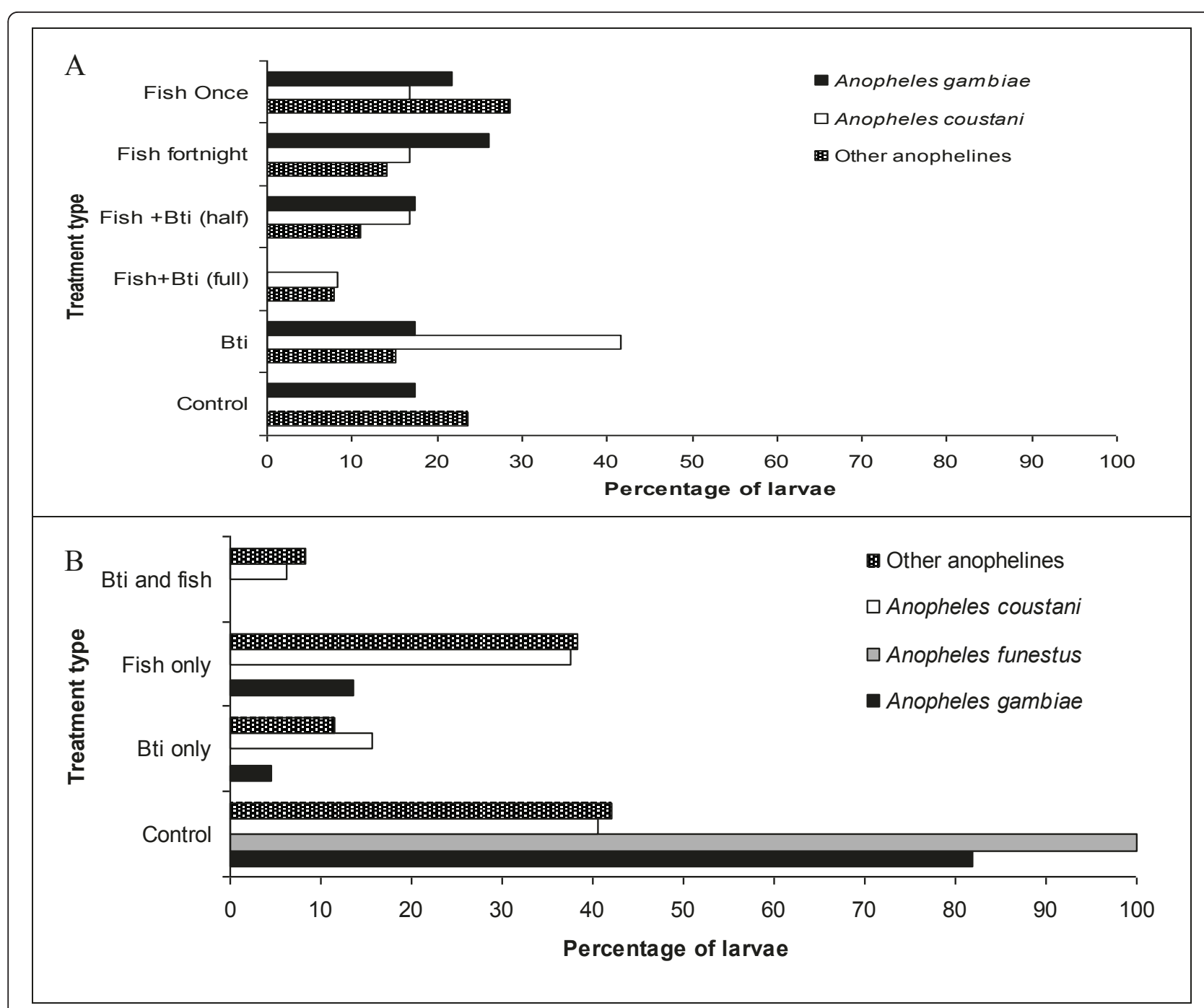

Figure 3 Anopheles gambiae, An. funestus and An. coustani larval distribution in the (A) ponds and (B) canal man-made habitats under different treatments expressed as a percentage of the total number of larvae recorded.

carried out in Eritrea [19]. With a two weeks interval, our results show a low impact of Bti only on larval abundance. However studies by Fillinger and Lindsay [16] and Majambere et al. [18], report microbial larvicides such as Bti to have greater efficacy (95\%) when applied to anopheline larval habitats in optimum quantities on a weekly basis. If weekly application of $B t i$ would have been followed, then habitats provided with Bti only may have been as effective as those provided with $B t i$ and fish on larval abundance. In addition, the persistence of Bti endotoxins in our study may have reduced rapidly under field conditions, hence showing no apparent effect on anopheline larval abundance. As previous studies clearly showed that $B t i$ is non toxic to non-target organisms [16,30], we used this property of $B t i$ to serve as a basis for integrating this product with $G$. affinis for increased efficacy of larval control.
The trials in this study were done under field conditions in man-made habitats that were naturally colonized by mosquito larvae. Under these conditions, external factors were not controlled and could have played an important role in the colonization and growth of mosquito larvae in the respective habitats. The variations in water level and occasional flooding of habitats could not be avoided, as the sites were exposed to ambient conditions. Factors such as water turbidity, nutrient content in water, cannibalism, predation of immature stages, parasitism, pathogens, competition, water temperature and plant odours that could have either repelled or attracted female mosquitoes during oviposition [41-47] were not controlled and hence could have played a role in the results obtained. All larval stages of culicine mosquitoes increased as vegetation cover increased progressively from man-made ponds, small 
water canals, rice paddies to swamps. Habitats with few anopheline larvae recorded more culicine larvae, while those that recorded more anophelines had fewer culicine larvae. This suggests selective oviposition behaviour among these mosquito families $[37,48,49]$. In Nyalenda, the water present in breeding habitats was often polluted with debris and human waste, which might have favored proliferation of culicine mosquitoes (data not shown) and at the same time water quality may have had a negative impact on the efficacy of the treatments provided. Competition and differences in the physicalchemical characteristics of the water may have played a role in structuring larval populations, although these factors were not investigated in this study. The standard dipping method was used to estimate mosquito larval densities, which may have underestimated larval abundance $[28,50,51]$ and consequently, may have influenced the amounts of Bti and numbers of G. affinis used, leading to contrasting results.

In western Kenya, areas that were previously natural swamps and forests have been transformed into agricultural fields mainly due to human population pressure [2]. These agricultural developments have an impact on the ecological characteristics of the local mosquito vector in terms of density, local microclimate and malaria incidence $[2,33,52,53]$. Communities in western Kenya are willing to take part in malaria control [27] and to effect this, simple control strategies suitable for the local of mosquito vectors need to be available as a way of adapting to the changes in land use. Results from this study indicate that locally available leafy plants could be used for mosquito control especially in areas under traditional agriculture. Use of edible fish [40] and mosquito fish are other options that can easily be put into practice, especially in areas where water is always present.

The effectiveness of biological larvicides for the control of African anophelines has already been demonstrated by several studies $[16,17,54]$ and in areas where locally available solutions are not feasible and where water cannot be drained, then application of microbial larvicides could be the best option. Although our results are spatially and temporally limited, the option of using shade from locally available crops and predatory fish seems an easily applicable alternative for the control of mosquito larvae. More importantly, as the level of morbidity resulting from the specific problem of malaria is a net result of a balance between livelihood and ecosystem factors [55] an ecohealth approach to malaria control is bound to produce discernable and long lasting effects.

This study was part of an ongoing project in different agro-ecological settings in two highland villages (Lunyerere and Fort Ternan) and one peri-urban area (Nyalenda), where most larval habitats were man-made [5]. The field studies reported in this paper were done in the peri-urban area of Kisumu town to assess the best options of controlling immature mosquitoes. For Nyalenda, larviciding and use of predatory fish seem promising and can be supplemented with the existing adulticiding options.

\section{Acknowledgements}

We are grateful to Tedd Omondi, Paul Mabuka, Amos Wawire and Annet Obukosia for their tireless support during field sampling and mosquito identification in the laboratory. We are grateful to Mr. David Madahana for his role in driving us to and from the field. Dr. Andrew Githeko is acknowledged for institutional support provided during the field study. Drs. Ron van Lammeren and Krijn Paaijmans are thanked for helpful comments and suggestions on the draft version of this paper. We wish to acknowledge the Inland waters manager and the staff at KEMFRI Kisumu for the tremendous support provided in the establishment of fish colony. Financial support was provided by the Dioraphte Foundation, The Netherlands.

\section{Author details}

${ }^{1}$ Laboratory of Entomology, Wageningen University, P.O. Box 8031, $6700 \mathrm{EH}$ Wageningen, The Netherlands. ${ }^{2}$ International Centre of Insect Physiology and Ecology, P.O. Box 30772 - 00100 GPO, Nairobi, Kenya. ${ }^{3}$ School of Biological Sciences, University of Nairobi, P.O. Box 30197-00100 GPO, Nairobi, Kenya.

\section{Authors' contributions}

SSI and CKM designed study, carried out data collection and writing of the manuscript. SSI performed the statistical analysis. WT and RW assisted with study design and in editing of the manuscript. All authors read and approved the final version of manuscript.

\section{Conflict of interest statement}

We declare that we have no conflict of interest. This work was part of the project funded by the Dioraphte Foundation, The Netherlands. The funding organization had no role in the analysis or interpretation of the results or in the drafting of the manuscript.

Received: 22 April 2011 Accepted: 6 July 2011 Published: 6 July 2011

\section{References}

1. Lindblade KA, Walker ED, Onapa AW, Katungu J, Wilson ML: Land use change alters malaria transmission parameters by modifying temperature in a highland area of Uganda. Trop Med Int Health 2000, 5:263-274.

2. Munga S, Minakawa N, Zhou GF, Mushinzimana E, Barrack OOJ, Githeko AK, Yan GY: Association between land cover and habitat productivity of malaria vectors in western Kenyan highlands. Am J Trop Med Hyg 2006, 74:69-75.

3. Norris DE: Mosquito-Borne Diseases as a consequence of land use change. EcoHealth 2004, 1:19-24.

4. Walsh JF, Molyneux DH, Birley MH: Deforestation: effects on vector-borne disease. Parasit 1993, 106:55-75.

5. Imbahale SS, Paaijmans KP, Mukabana WR, Lammeren R, Githeko AK, Takken W: A longitudinal study on Anopheles mosquito larval abundance in distinct geographical and environmental settings in western Kenya. Malar J 2011, 10:81.

6. Klinkenberg E, Takken W, Huibers F, Toure YT: The phenology of malaria mosquitoes in irrigated rice fields in Mali. Act Trop 2003, 85:71-82.

7. Matthys B, N'Goran EK, Kone M, Koudou BG, Vounatsou P, Cisse G, Tschannen AB, Tanner M, Utzinger J: Urban agricultural land use and characterization of mosquito larval habitats in a medium-sized town of Cote d'Ivoire. J Vec Ecol 2006, 31:319-333.

8. Mwangangi JM, Muturi EJ, Shililu Jl, Jacob B, Kabiru EW, Mbogo CM Githure JI, Novak RJ: Distribution of mosquito larvae within the paddy and its implication in larvicidal application in Mwea Rice Irrigation Scheme, Central Kenya. J Am Mosa Control Assoc 2008, 24:36-41.

9. Imbahale SS: Integrated Malaria vector control in different agro-ecosystems in western Kenya, PhD Thesis Wageningen University, The Netherlands; 2009. 
10. Floore TG: Mosquito larval control practices: past and present. J Am Mosq Control Assoc 2006, 22:527-533.

11. Killeen GF, Fillinger U, Knols BG: Advantages of larval control for African malaria vectors: low mobility and behavioural responsiveness of immature mosquito stages allow high effective coverage. Malar J 2002, 1:8.

12. Liu WH, Xin K, Chao CZ, Feng SZ, Yan L, He RZ, Zhang ZH, Gibson G, Kang WM: New irrigation methods sustain malaria control in Sichuan Province, China. Act Trop 2004, 89:241-247.

13. Keiser J, Singer $\mathrm{BH}$, Utzinger J: Reducing the burden of malaria in different eco-epidemiological settings with environmental management: a systematic review. Lancet Infect Dis 2005, 5:695-708.

14. Kitron $U$, Spielman A: Suppression of transmission of malaria through source reduction: antianopheline measures applied in Israel, the United States, and Italy. Rev Infect Dis 1989, 11:391-406.

15. Utzinger J, Tozan Y, Doumani F, Singer BH: The economic payoffs of integrated malaria control in the Zambian copperbelt between 1930 and 1950. Trop Med Int Health 2002, 7:657-677.

16. Fillinger $U$, Lindsay SW: Suppression of exposure to malaria vectors by an order of magnitude using microbial larvicides in rural Kenya. Trop Med Int Health 2006, 11:1629-1642.

17. Geissbuhler Y, Kannady K, Chaki PP, Emidi B, Govella NJ, Mayagaya V, Kiama M, Mtasiwa D, Mshinda H, Lindsay SW, Tanner M, Fillinger U, Castro MC, Killeen GF: Microbial Larvicide Application by a Large-Scale, Community-Based Program Reduces Malaria Infection Prevalence in Urban Dar Es Salaam, Tanzania. PLoS ONE 2009, 4(3):e5107.

18. Majambere S, Fillinger U, Sayer DR, Green C, Lindsay SW: Spatial distribution of mosquito larvae and the potential for targeted larval control in The Gambia. Am J Trop Med Hyg 2008, 79:19-27.

19. Shililu JI, Tewolde GM, Brantly E, Githure Jl, Mbogo CM, Beier JC, Fusco R, Novak RJ: Efficacy of Bacillus thuringiensis israelensis, Bacillus sphaericus and temephos for managing Anopheles larvae in Eritrea. J Am Mosq Control Assoc 2003, 19:251-258.

20. Vanek MJ, Shoo B, Mtasiwa D, Kiama M, Lindsay SW, Fillinger U, Kannady K, Tanner M, Killeen GF: Community-based surveillance of malaria vector larval habitats: a baseline study in urban Dar es Salaam, Tanzania. BMC Public Health 2006, 6:154

21. Rose Rl: Pesticides and Public Health: Integrated Methods of Mosquito Management. Emerg Infect Dis 2001, 20:1.

22. Beales PF, Gillies HM: Rationale and technique of malaria control. Essential Malariology London: Arnold, a member of the Hodder Headline Group; 2002.

23. Shiff C: Integrated approach to malaria control. Clin Microbiol Rev 2002 15:278-293.

24. Becker $\mathrm{N}$ : Ice granules containing endotoxins of microbial agents for the control of mosquito larvae-a new application technique. J Am Mosq Control Assoc 2003, 19:63-66.

25. Matias RJ, Adrias AQ: The use of annual killifish in the biocontrol of the aquatic stages of mosquito in temporary bodies of fresh water: apotential new tool in vector control. Parasit Vectors 2010, 3:46.

26. Reichard M, Watters BR, Wildekamp HR, Sonnenberg R, Nagy B, Polačik M, Valdesalici S, Cellerino A, Cooper BJ, Hengstler H, Rosenstock J, Sainthouse I: Potential negative impacts and low effectiveness in the use of African annual killifish in the biocontrol of aquatic mosquito larvae in temporary water bodies. Parasit Vectors 2010, 3:89.

27. Imbahale SS, Fillinger U, Githeko AK, Mukabana WR, Takken W: An exploratory survey of malaria prevalence and people's knowledge, attitudes and practices of mosquito larval source management for malaria control in western Kenya. Act Trop 2010, 115:248-256.

28. Service MW: Mosquito Ecology - Field Sampling Methods Elsevier Applied Science, London; 1993.

29. Gillies MT, Coetzee M: A supplement to the Anophelinae of Africa South of the Sahara The South African Institute for Medical Research, Johannesburg; 1987.

30. Fillinger U, Knols BG, Becker N: Efficacy and efficiency of new Bacillus thuringiensis var israelensis and Bacillus sphaericus formulations against Afrotropical anophelines in Western Kenya. Trop Med Int Health 2003, 8:37-47.

31. Petrarca V, Sabatinelli G, Toure YT, di Deco MA: Morphometric multivariate analysis of field samples of adult Anopheles arabiensis and An. gambiae s.s. (Diptera: Culicidae). J Med Entomol 1998, 35:16-25.

32. Foley DH, Torres EP, Mueller I: Stream-bank shade and larval distribution of the Philippine malaria vector Anopheles flavirostris. Med Vet Entomol 2002, 16:347-355.
33. Munga S, Minakawa N, Zhou GF, Barrack OOJ, Githeko AK, Yan GY: Oviposition site preference and egg hatchability of Anopheles gambiae: Effects of land cover types. J Med Entomol 2005, 42:993-997.

34. Mwangangi JM, Muturi EJ, Shililu JI, Muriu S, Jacob B, Kabiru EW, Mbogo CM, Githure Jl, Novak RJ: Environmental covariates of Anopheles arabiensis in a rice agro ecosystem in Mwea, Central Kenya. J Am Mosa Control Assoc 2007, 23:371-377.

35. Wamae PM, Githeko AK, Menya MD, Takken W: Shading by Napier grass reduces Malaria vector larvae in Natural habitats in Western Kenya highlands. EcoHealth 2010, Online July 2010

36. Goma LKH: Experimental Breeding of Anopheles gambiae Giles in Papyrus Swamps. Nature 1960, 187:1137-1138.

37. Tuno N, Okeka W, Minakawa N, Takagi M, Yan G: Survivorship of Anopheles gambiae sensu stricto (Diptera: Culicidae) larvae in western Kenya highland forest. J Med Entomol 2005, 42:270-277.

38. Blaustein L: Larvivorous fishes fail to control mosquitoes in experimental plots. Hydrobiologia 1992, 232:219-232.

39. Homski D, Goren M, Gasith A: Comparative evaluation of the larvivorous fish Gambusia affinis and Aphanius dispar as mosquito control agents. Hydrobiologia 1994, 284:137-146.

40. Howard AF, Zhou G, Omlin FX: Malaria mosquito control using edible fish in western Kenya: preliminary findings of a controlled study. BMC Public Health 2007, 7:199.

41. Koenraadt CJM, Takken W: Cannibalism and predation among larvae of the Anopheles gambiae complex. Med Vet Entomol 2003, 17:61-66.

42. Okogun GR, Anosike JC, Okere AN, Nwoke BE: Ecology of mosquitoes of Midwestern Nigeria. J Vector Borne Dis 2005, 42:1-8.

43. Paaijmans KP, Huijben S, Githeko AK, Takken W: Competitive interactions between larvae of the malaria mosquitoes Anopheles arabiensis and Anopheles gambiae under semi-field conditions in western Kenya. Act Trop 2009, 109:124-130.

44. Schneider P, Takken W, McCall PJ: Interspecific competition between sibling species larvae of Anopheles arabiensis and An. gambiae. Med Vet Entomol 2000, 14:165-170.

45. Service MW: Studies on sampling larval populations of the Anopheles gambiae complex. Bull World Health Organ 1971, 45:169-180.

46. Service MW: Mortalities of the larvae of the Anopheles gambiae Giles complex and detection of predators by the precipitin test. Bull Entomol Res 1973, 62:359-369.

47. Service MW: Mortalities of the immature stages of species B of the Anopheles gambiae complex in Kenya: Comparison between rice fields and temporary pools, identification of predators and effects of insecticidal spraying. J Med Entomol 1977, 13:535-545.

48. Eitam A, Blaustein L: Oviposition habitat selection by mosquitoes in response to predator (Notonecta maculata) density. Physiological Entomol 2004, 29(2):188-191.

49. Takken W: Odor-Mediated behaviour of Afrotropical malaria mosquitoes. Annual Rev Entomol 1999, 44:131-157.

50. Gu W, Utzinger J, Novak RJ: Habitat-based larval interventions: a new perspective for malaria control. Am J Trop Med Hyg 2008, 78:2-6.

51. Mutuku FM, Bayoh MN, Gimnig JE, Vulule JM, Kamau L, Walker ED, Kabiru E, Hawley WA: Pupal habitat productivity of Anopheles gambiae complex mosquitoes in a rural village in western Kenya. Am J Trop Med Hyg 2006, 74:54-61.

52. Minakawa N, Munga S, Atieli F, Mushinzimana E, Zhou GF, Githeko AK, Yan GY: Spatial distribution of anopheline larval habitats in Western Kenyan highlands: Effects of land cover types and topography. Am J Trop Med Hyg 2005, 73:157-165.

53. Yasuoka J, Levins R: Impact of deforestation and agricultural development on anopheline ecology and malaria epidemiology. Am J Trop Med Hyg 2007, 76:450-460.

54. Majambere S, Lindsay SW, Green C, Kandeh B, Fillinger U: Microbial larvicides for malaria control in The Gambia. Malar J 2007, 6:76.

55. Mutero C, Kabutha L, Kabuage V, Kimani G, Gitau J, Ssennyonga L, Githure J: Livestock and Agro-ecosystem Management for Community-based Integrated Malaria Control (East Africa), IDRC report number 1004822003.

doi:10.1186/1756-3305-4-130

Cite this article as: Imbahale et al:: Development of environmental tools for anopheline larval control. Parasites \& Vectors 2011 4:130. 